\title{
Histological Studies on Digestive System Development and Early Feeding Activity of Pangasius Hybrid Larvae
}

\author{
Agus Putra A. Samad ${ }^{1 *}$, M. Fauzan Isma ${ }^{1}$, Rindhira Humairani ${ }^{2}$ and Yusrizal Akmal ${ }^{2}$ \\ ${ }^{1}$ Department of Aquaculture, Faculty of Agriculture, Samudra University, Jl. Meurandeh, Langsa \\ Lama, Langsa 24353, Indonesia \\ ${ }^{2}$ Department of Aquaculture, Faculty of Agriculture, Almuslim University, Jl. Almuslim \\ Matangglumpangdua, Bireun 24261, Indonesia
}

*Correspondence :
agus.putra.samad@gmail.com

Received : 2019-10-27

Accepted : 2019-12-30

Keywords :

Pangasius, Hybrid, Digestive system, Exogenous feeding

\begin{abstract}
This study was conducted to investigate the digestive system development and early feeding activities of Pangasius hybrid larvae to determine the exogenous feeding period. Four crossbreeding programs in triplicate were examined between Pangasius hypophthalmus and P. Nasutus, named $\mathrm{HH}, \mathrm{HN}, \mathrm{NH}$, and NN. Results showed that the digestive systems of both hybrid larvae ( $\mathrm{HN}$ and $\mathrm{NH}$ ) were poorly developed immediately after hatching. Artemia was first seen in the gastrointestinal tract of the hybrid larvae at 54-hAH. However, the onset of exogenous feeding was detected at 60$\mathrm{hAH}$. The digestive system of the new hybrid larvae consisted of a straight undifferentiated tube and anus still closed. The gastrointestinal tract, liver, and pancreas were formed and developed by 2-dAH. The zymogen granules were also observed in the pancreas and thus implied that the pancreas function started before the exogenous feeding period. It concluded that $60-\mathrm{hAH}$ was the critical period for hybrid larvae. Therefore it should be provided with appropriated feed to avoid mortality.
\end{abstract}

\section{INTRODUCTION}

Early fish development is the essential thing that should be known before producing any seeds, especially in the new cultured species or strain. Generally, the egg stage is divided into the early, middle, and late subdivisions, which end with blastopore closure, freeing of the tailbud from the yolk, and hatching. After hatching, the intestine is considered as the most vital organ in supporting their life due to the digestion and absorption process of nutrients (Chowdhary et al., 2013; Roberts, 2012).

Even though, embryonic period mostly depends on temperature and oxygen supply to support their survival rate, yet, the availability of food also plays a significant role (Hassan et al., 2011). For the exogenously feeding larvae, the functional of food acquisition and growth is decisive (Schiemer et al., 2002). Thus, it is crucial to know when the yolk sac is exhausted, and the larvae start to feed actively because this period is recognized as a critical period that determines the survival of the next stages. Furthermore, Southgate and Lucas (2003) stated when larvae first hatch. They usually have sufficient energy reserves in the yolk sac to support development for a day or more before they need to be fed.

Considering that the digestive system during the larval stage is still 
indigent, therefore, understanding the mouth gape is essential in relating to larvae first feeding. Lavens and Sorgeloos (1996) as well as Petkam and Moodie (2001) stated that during the first feeding activity, fish larvae mostly depend on small live prey which is easy to be ingested.

It is well-known that the digestive system in larvae is different from juveniles and adults. Therefore, the nutrition requirements of early life stages are distinct from those of older fish (De Silva and Anderson, 1994). Concerning their digestive organ, larval stages also significantly differ from the adult. The larvae have only a simple digestive system. Consequently, larvae need specific diets such as live feed or specially formulated feed. However, without any further information on gastrointestinal tract development, the status of digestion ability is a mystery. Therefore, a good understanding of fish digestion ability is essential to know the capability of fish larvae in receiving or ingesting feed. Thus, the objectives of this study were to describe the histology of digestive system development in the early feeding activity of pangasius hybrid larvae.

\section{METHODOLOGY}

\section{Place and Time}

This study was conducted in Aquaculture Laboratory of Institute of Tropical Aquaculture, University Malaysia Terengganu and Freshwater Breeding and Technology Research Office, Sukamandi, Indonesia.

\section{Research Material}

The tools used in the study include microscopes, aquariums, digital scale, dissecting set, digital ruler, microtome, water bath, fixation materials, paraffin, alcohol, formalin, xylene, hematoxylin, eosin, Artemia, and water quality measurement tools. The materials used to support this study was pangasius hybrid larvae.

\section{Research Design}

The experimental design used in this study was completely randomized. Two pangasius species were used in producing hybrid larvae, named Pangasius hypophthalmus and P. nasutus. Breeders of pangasius with a mean weight of $3.25 \pm 0.5 \mathrm{~kg}$ (females) and $2.4 \pm 0.3 \mathrm{~kg}$ (males) were used for the experiment. During acclimatization, spawners were fed with commercial pellets, and water quality was controlled daily. Four different mating programs were practiced: 1 . HH Control (female $P$. hypopthalmus $\mathrm{x}$ male $P$. hypopthalmus); 2. NN Control (female $P$. nasutus $\mathrm{x}$ male P. nasutus); 3. HN Crossbreeding (female $P$. hypopthalmus $\mathrm{x}$ male $P$. nasutus); and 4. NH Crossbreeding (female $P$. nasutus $\mathrm{x}$ male $P$. hypopthalmus).

Three replicates of each mating program were treated using artificial breeding practice. The eggs and sperm were collected by stripping the breeders' abdomen. Then the gametes were stirred and mixed up thoroughly until eggs fertilized equally. The eggs were then transferred into a hatching tank during cleavage or hatching periods.

\section{Work Procedures Early Feeding}

The larvae (1 day after hatching) were fed continuously with newly hatched Artemia to investigate the exogenous feeding activity. In 6 hours, larvae were collected and then preserved in $5 \%$ formalin and dissected under a microscope to observed whether Artemia exists in the digestive tract. The existence of Artemia in the digestive system would be considered as the starting time of exogenous feeding.

\section{Digestive Tract Development}

From the first day after hatching (1 $\mathrm{dAH}$ ) until $7 \mathrm{dAH}$, around ten larvae were sampled daily from the rearing tank (500-liter fiberglass tank) and immediately preserved in 10\% buffered formalin before histological processes as 
described in the histological method section.

\section{Histological Method}

For the histological study, sample specimens were fixed in Bouin's solution and processed following routine methods by Drury et al. (1967). Then, the samples were stained with hematoxylin and eosin. Each development stage was identified based on histological observation. The histology studies were using standard procedures as follows:

Specimen: The specimens were cut into a thin section for the fast penetration of the fixative. Before the process begins, the tissue should have enough time in the fixative. The specimens were placed immediately in the fixative. Fixation: The specimens were then fixed into mechanically and biochemically stabilized in a common fixative bouin's solution.

Embedding: The specimens that have been fixed were dehydrated and embedded in wax. It requires that water should be removed from the tissue and then replaced by wax block, which later can be solidified to make a tissue block for the sectioning process. The tissue is dehydrated by immersing it in higher concentrations of alcohol (70 - 100\%), before transferring to the xylene solvent (clearing process) and finally impregnation in paraffin wax. Cutting/ Sectioning: the specimens were cut/ section into $4-7 \mu \mathrm{m}$ by using a rotary microtome and placed on a glass slide for staining.

Floating: The specimens were floated into $38-40{ }^{\circ} \mathrm{C}$ water baths. The samples were fixed to a glass slide by using Mayers Albumin. After the set, they were dried overnight on a hot plate at 60 ${ }^{\circ} \mathrm{C}$.

Staining: The procedures of staining processes were using xylene, alcohol, eosin, potassium acetate, hematoxylin, and DPX. The slides of the specimens were mounted and viewed under a microscope to observe the development of the digestive systems.

\section{Data Analysis}

The data obtained from the experiment were analyzed using descriptive analysis. Once the results obtained, the data were presented in tables and figures.

\section{RESULTS AND DISCUSSION Onset of Exogenous Feeding}

This experiment was conducted using the hatched larvae. Results exhibited that Artemia was presented in the digestive tract of $\mathrm{HN}$ larvae at 54hAH (Table 1). However, the onset of exogenous feeding was observed at 60$\mathrm{hAH}$ in the majority examined larvae. This finding was the same as shown in $\mathrm{HH}$ larvae, whereas the sampled larvae found out to ingest Artemia at 60hAH(Table 2).

Table 1. Number of Artemia presented in the digestion tract of HN larvae.

\begin{tabular}{|c|c|c|c|c|c|}
\hline \multicolumn{2}{|c|}{$\begin{array}{c}\text { Time Elapse After } \\
\text { Hatching }\end{array}$} & \multirow[t]{2}{*}{$\begin{array}{l}\text { No. of Larvae } \\
\text { Examined }\end{array}$} & \multirow{2}{*}{$\begin{array}{l}\text { No. of Larvae } \\
\text { Ingested on } \\
\text { Artemia }\end{array}$} & \multicolumn{2}{|c|}{$\begin{array}{c}\text { No. of Artemia in the } \\
\text { Gut }\end{array}$} \\
\hline Days & Hours & & & Range & Mean \\
\hline 1 & 42 & 30 & 0 & - & - \\
\hline 1 & 48 & 30 & 0 & - & - \\
\hline 2 & 54 & 30 & 11 & $1-7$ & 1.30 \\
\hline 2 & 60 & 30 & 22 & $3-13$ & 5.53 \\
\hline 2 & 66 & 30 & 30 & $7-24$ & 15.13 \\
\hline 3 & 72 & 30 & 30 & $36-63$ & 50.13 \\
\hline 3 & 78 & 30 & 30 & $27-116$ & 88.60 \\
\hline
\end{tabular}


Table 2. Number of Artemia presented in the digestion tract of $\mathrm{HH}$ larvae.

\begin{tabular}{|c|c|c|c|c|c|}
\hline \multicolumn{2}{|c|}{$\begin{array}{l}\text { Time Elapse After } \\
\text { Hatching }\end{array}$} & \multirow[t]{2}{*}{$\begin{array}{l}\text { No. of Larvae } \\
\text { Examined }\end{array}$} & \multirow{2}{*}{$\begin{array}{l}\text { No. of Larvae } \\
\text { Ingested on } \\
\text { Artemia }\end{array}$} & \multicolumn{2}{|c|}{$\begin{array}{l}\text { No. of Artemia in the } \\
\text { Gut }\end{array}$} \\
\hline Days & Hours & & & Range & Mean \\
\hline 1 & 42 & 30 & 0 & - & - \\
\hline 1 & 48 & 30 & 0 & - & - \\
\hline 2 & 54 & 30 & 9 & $2-6$ & 1.43 \\
\hline 2 & 60 & 30 & 21 & $1-17$ & 5.23 \\
\hline 2 & 66 & 30 & 30 & $1-20$ & 17.30 \\
\hline 3 & 72 & 30 & 30 & $15-86$ & 53.47 \\
\hline 3 & 78 & 30 & 30 & $26-126$ & 85.36 \\
\hline
\end{tabular}

On the other hand, similar results found out that Artemia was also observed in the digestive tract of $\mathrm{N} \mathrm{H}$ larvae at 54hAH (Table 3). It also confirmed that exogenous feeding was seen at $60-\mathrm{hAH}$, whereas the majority of the sample ingested Artemia. This similar result also found in NN larvae, whereas larvae found out to swallow Artemia at 60-hAH (Table 4).

Table 3. Number of Artemia presented in the digestion tract of NH larvae.

\begin{tabular}{cccccc}
\hline \multicolumn{2}{c}{$\begin{array}{c}\text { Time Elapse After } \\
\text { Hatching }\end{array}$} & $\begin{array}{c}\text { No. of Larvae } \\
\text { Examined }\end{array}$ & $\begin{array}{c}\text { No. of Larvae } \\
\text { Ingested on } \\
\text { Artemia }\end{array}$ & \multicolumn{2}{c}{$\begin{array}{c}\text { No. of Artemia in the } \\
\text { Gut }\end{array}$} \\
\hline 1 & Hours & & 0 & - & Mean \\
\hline 1 & 42 & 30 & 0 & - & - \\
2 & 48 & 30 & 12 & $1-12$ & 2.70 \\
2 & 54 & 30 & 23 & $5-24$ & 12.33 \\
2 & 60 & 30 & 30 & $19-61$ & 39.77 \\
3 & 66 & 30 & 30 & $21-98$ & 66.40 \\
3 & 72 & 30 & 30 & $23-138$ & 90.40 \\
\hline
\end{tabular}

Table 4. Number of Artemia presented in the digestion tract of NN larvae.

\begin{tabular}{|c|c|c|c|c|c|}
\hline \multicolumn{2}{|c|}{$\begin{array}{c}\text { Time Elapse After } \\
\text { Hatching }\end{array}$} & \multirow[t]{2}{*}{$\begin{array}{l}\text { No. of Larval } \\
\text { Examined }\end{array}$} & \multirow{2}{*}{$\begin{array}{l}\text { No. of Larval } \\
\text { Ingested on } \\
\text { Artemia }\end{array}$} & \multicolumn{2}{|c|}{$\begin{array}{c}\text { No. of Artemia in the } \\
\text { Gut }\end{array}$} \\
\hline Days & Hours & & & Range & Mean \\
\hline 1 & 42 & 30 & 0 & - & - \\
\hline 1 & 48 & 30 & 0 & - & \\
\hline 2 & 54 & 30 & 13 & $1-15$ & 2.83 \\
\hline 2 & 60 & 30 & 27 & $1-20$ & 8.25 \\
\hline 2 & 66 & 30 & 30 & $8-71$ & 36.70 \\
\hline 3 & 72 & 30 & 30 & $11-101$ & 62.25 \\
\hline 3 & 78 & 30 & 30 & $30-142$ & 94.12 \\
\hline
\end{tabular}

\section{Digestive Tract Development}

The result on histology showed that both hybrids ( $\mathrm{HN}$ and $\mathrm{NH}$ ) larvae hatched with the undeveloped digestive system as observed externally. The digestive system of the newly hatched larvae consisted of straight undifferentiated tubes and anus still closed. An undifferentiated pancreas and liver were also present. Twenty-four hours later or at $1 \mathrm{dAH}$, the pancreas was differentiated as a clump of cells, and the gut separates into a buccal cavity, esophagus, and simple digestive tube. Anus remained closed (Figure 1). 


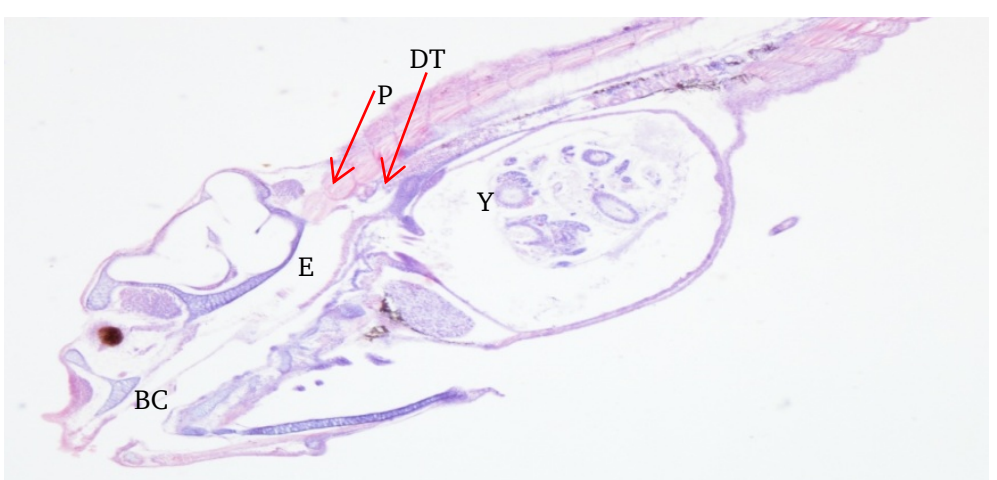

Figure 1. Longitudinal section of $\mathrm{HN}$ hybrid larvae at $1 \mathrm{dAH}$. BC: bud cavity; E: esophagus; Y: yolk sac; P: clump tissue of pancreas and liver; DT: digestive tube (magnification: 10X).

At $2 \mathrm{dAH}$, the liver and pancreas were developed actively (Figure 2A). Pancreas showed the development of Zymogen granules (Figure 2B). At this time, although most of the viscera cavity

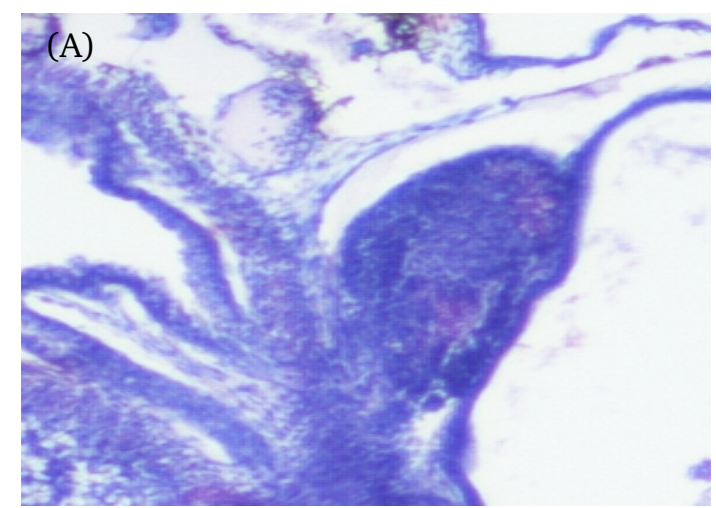

Figure 2. Longitudinal section of HN pancreas.(Magnifications 20X);

The intestine was developed and divided into three sections: intestine I, II, and III (Figure 3). Intestine I is characterized as sharp mucosal fold and continued towards intestine II. Intestine III consisted of a straight, thickened epithelial wall. At around 3-dAH, the intestine was developing well, and goblet was still filled with a large amount of yolk sac and no stomach formation detected, the development of the gastrointestinal tract started from its hind part near the anus was observed.

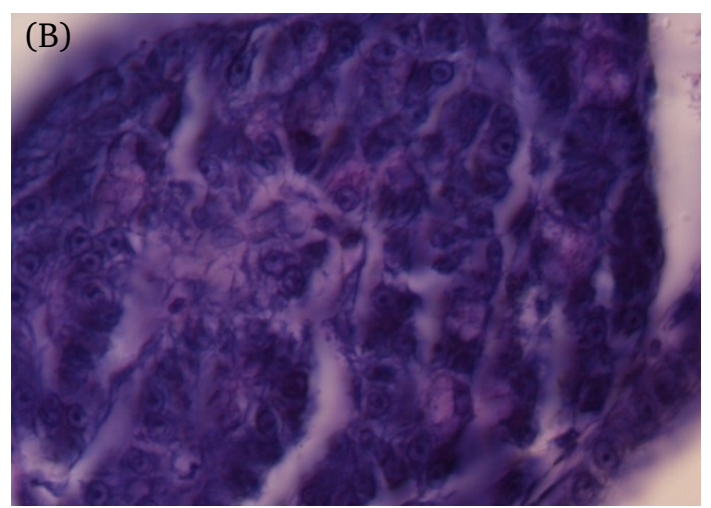

hybrid larvae at2 dAH. (A) P: (B) Z: zymogen granule (magnification 100X).

cells were apparent (Figure 4). However, in this stage, the gastric gland was not yet found in the stomach. At $6 \mathrm{dAH}$, the gastric glands were found beneath the gastric epithelium (Figure 5), and on the same day, the anus was formed entirely (Figure 6). 


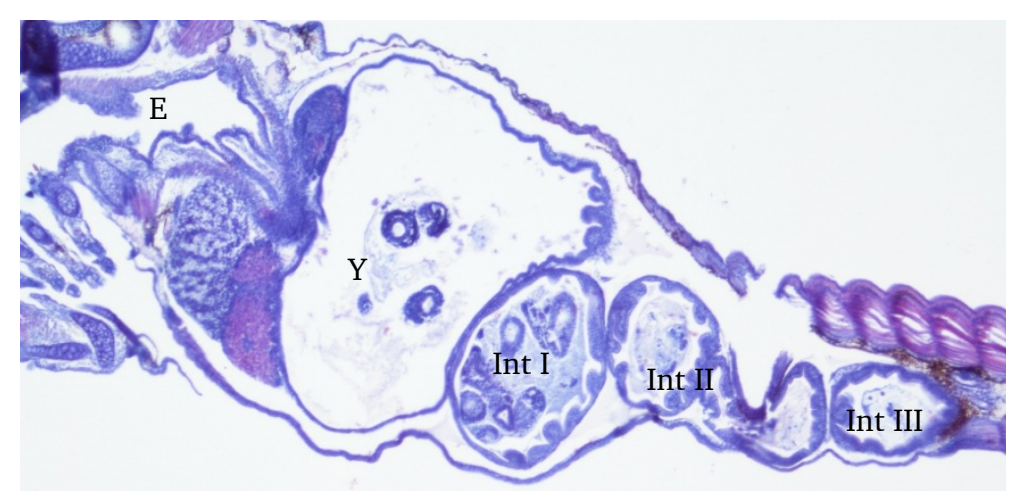

Figure 3. Longitudinal section of NH hybrid larvae at $2 \mathrm{dAH}$. E: esophagus; Int: intestine was well developed and divided into three sections: Int I, Int II, and Int III. and Y: At that time, the yolk remains (magnification: 20X).

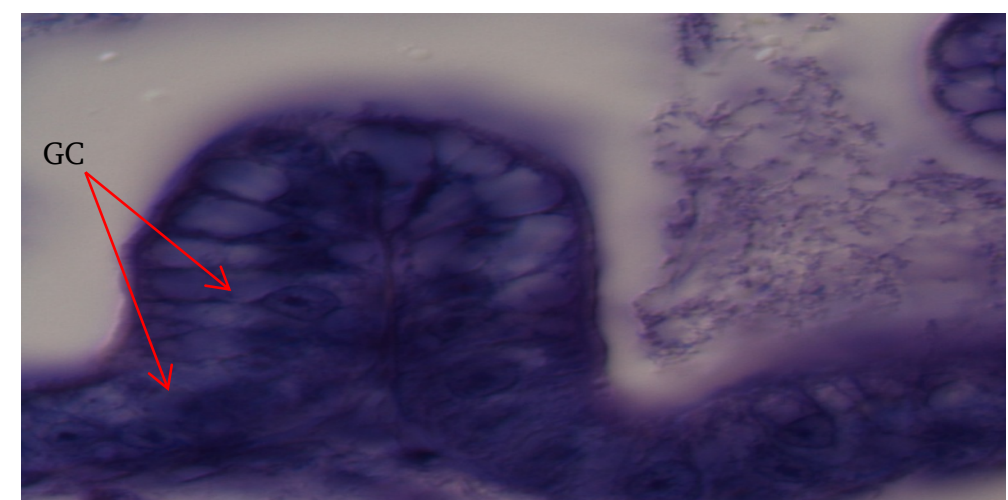

Figure 4. Longitudinal section of NH hybrid larvae at $3 \mathrm{dAH}$. GC: esophageal goblet cells (magnification 40X).

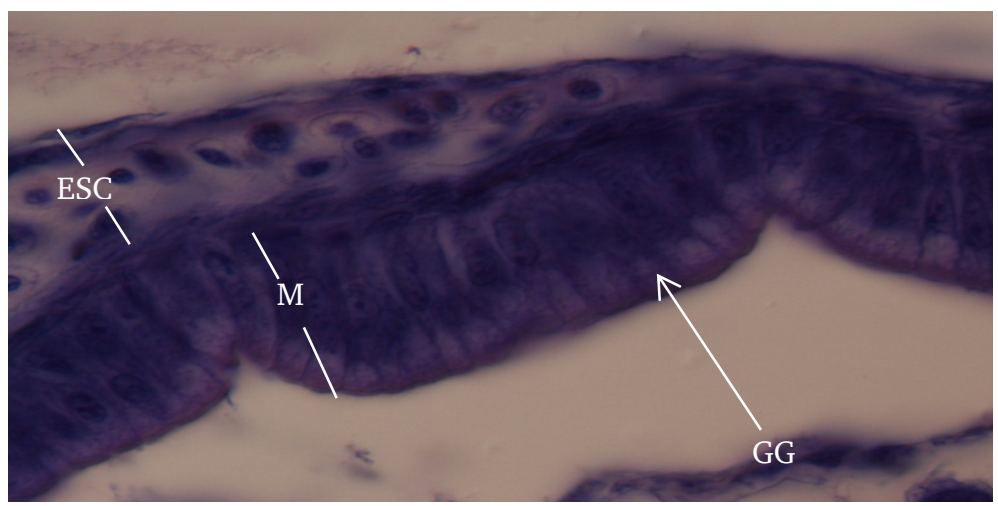

Figure 5. Longitudinal section of NH hybrid larvae at $6 \mathrm{dAH}$. ESC: esophageal stratum compactum; M: mucosa; and GG: gastric gland (magnification 40X). 


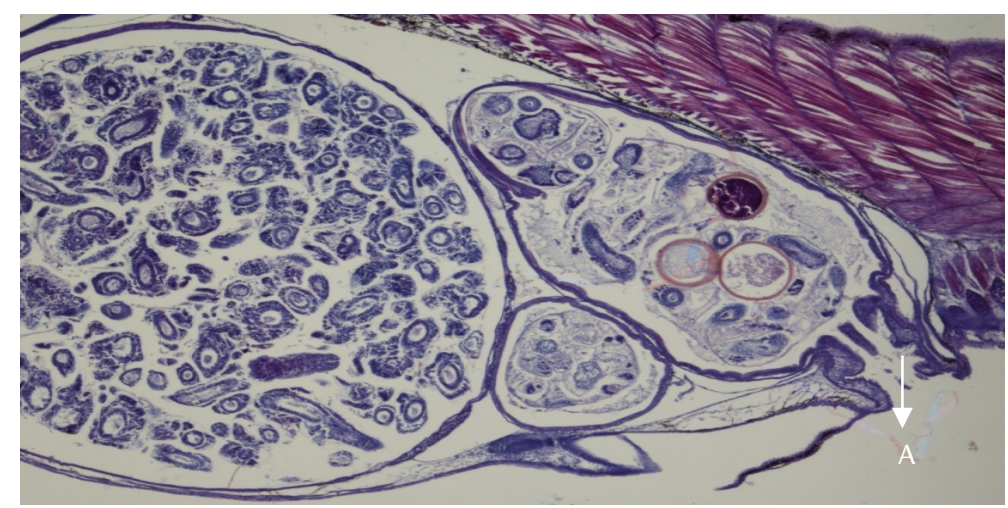

Figure6. Longitudinal section of $\mathrm{NH}$ hybrid larvae at $6 \mathrm{dAH}$. Showed A: completely formation of anus. (Magnification 40X).

Based on the result above, it can be mentioned that both $\mathrm{HN}$ and $\mathrm{NH}$ larvae showed their exogenous feeding at 60hAH. The same result was seen at both controls ( $\mathrm{HH}$ and $\mathrm{NN}$ ), whereas the exogenous food was at 60-hAH. It concluded that the larvae also undergo a mixed feeding period as reported in many species, including salmonid fish (Kamler, 1992). The existence of a mixed feeding period at the sampled larvae informed that they get through rapid eye formation, mouth, and digestive tract development. These similar findings also reported in catfish (Morni, 2003).

Besides, HN larvae reached $6.25 \pm 0.23 \mathrm{~mm}$ in total length on their first feeding. Commonly, this size was smaller than other catfish species. It has been reported that the length of Clarias microcephalus (Morni, 2003) reached $9.25 \pm 0.31 \mathrm{~mm}$ on their first feeding. On the other hand, $\mathrm{NH}$ larvae showed a length of $9.48 \pm 0.37 \mathrm{~mm}$ on their first feeding. It was bigger compared with other species, including catfish (Morni, 2003) and seabass (Walford and Lam, 1993).

Furthermore, it also noticed that both larvae $\mathrm{HN}$ and $\mathrm{NH}$ have a more massive mouth gape during the exogenous feeding. It analyzed, the mouth gape of $\mathrm{HN}$ was $1.04 \mathrm{~mm}$, and $\mathrm{NH}$ was $0.88 \mathrm{~mm}$. As comparable, Morni (2003) stated, the mouth opening of catfish during exogenous feeding only $0.86 \mathrm{~mm}$, whereas marble goby $0.29 \mathrm{~mm}$ (Pham, 2001). This illustrated that HN and $\mathrm{NH}$ larvae have benefits, whereas the larger mouth opening could lead to consuming more extensive live feed or prey to support their early life.

The digestive system of both hybrid ( $\mathrm{HN}$ and $\mathrm{NH}$ ) larvae was similar and poorly developed when they just hatched. Its alimentary canal only consisted of the straight undifferentiated tube as that found in most larva fish such as $P$. Bocourti (Tuan et al., 2002) and Lates calcarifer (Walford and Lam, 1993). It implies that fish larvae do not require a complex digestive system for yolk resumption. At 2-dAH, the gastrointestinal tract, liver, and pancreas were formed and developed before the yolk sac was exhausted. A similar finding was found in $C$. gariepinus, where most of the digestive organs, including the liver and pancreas, developed during the yolk sac period (Verrethet al., 1992). However, it was considered faster when compared to other species.

Correspondence

to the development of the pancreas, Verreth et al. (1992) mentioned that the presence of zymogen granules in the pancreas indicated an accumulation of digestive enzymes produced by the exocrine pancreas. In this study, it was observed that zymogen granules were present in the pancreas during the second day after hatching. It showed that one part of their digestive system had been developed well, which is also occurring in other fastgrowing catfish such as Pangasius bocourti (Tuan et al., 2002). However, in 
slow-growing species, O. marmoratus, zymogen granules only can be detected in 25-day old larvae (Pham, 2001).

Further observation was found that the stomach of both hybrid larvae has been developed during the exogenous feeding period. Since there were no gastric glands located under the epithelial layer, this new stomach may still not function well in food digestion. However, at least at that time, it can be able to store newly ingested food. This observation was similar to that found in P. bocourti (Tuan et al., 2002) and C. gariepinus (Verreth et al., 1992). In some species, like in Lates calcarifer, their stomach is still unformed at the early stage of exogenous feeding periods (Walford and Lam, 1993). Since the stomach could not secrete the enzyme, the digestion of ingested food took place in the intestine. In this case, the digestion process was stimulated by the trypsin enzyme that was secreted by the pancreas.

However, if the stomach is not functioning, the efficiency of digestion through this mechanism is strictly limited. Thus, at this stage, larvae have to rely on a food source that contains an enzyme system, which allows autolysis (Lavens and Sorgeloos, 1996). It was among the significant reasons why most fish larvae could not accept formulated feed as well as live food during the early stage of the exogenous feeding period.

In terms of the gastric gland, according to Walford and Lam (1993), the gastric gland contains an abundant of secretory granules. In this study, the gastric gland has been distinguished in the stomach of both ( $\mathrm{HN}$ and $\mathrm{NH}$ ) hybrid larvae at $6 \mathrm{dAH}$. These findings were similar to those found in $C$. microcephalus hybrid (Morni, 2003) and P. bocourti (Tuan et al., 2002), whereas, in $P$. bocourti, the gastric gland can be distinguished on the third day of exogenous feeding, while the mucus secretion can be detected during the following day. In other words, if the exocrine pancreas is responsible for producing an enzyme for intestinal lumen, the gastric glands play an essential role in the stomach.

\section{CONCLUSION}

The present study found that the first mouth opening of $\mathrm{HN}$ and $\mathrm{NH}$ larvae was at 54-hAH. However, the onset of exogenous feeding was confirmed at 60 hAH. The digestive systems of both hybrid larvae were poorly developed immediately after hatching. The gastrointestinal tract, liver, and pancreas were formed and developed by $2-\mathrm{dAH}$.

\section{ACKNOWLEDGEMENT}

We thank all parties who have aided in the completion of this research.

\section{REFERENCES}

Chowdhary, S., Srivastava, P.P., Jena, J., Yadav, A.K., Dayal, R., Mishra, S. and Srivastava, S.M., 2013. Histological studies of the intestine in threatened Asian catfish (Clarias batrachus) fingerlings fed with animal or plant origin protein blended with glucosamine.International Journal of Fisheries and Aquatic Studies, 1(2), pp.50-55. http://krishi.icar. gov.in/jspui/handle/123456789/46 74.

De Silva, S.S. and Anderson, T.A., 1994. Fish nutrition in aquaculture (Vol. 1). Springer Science \& Business Media.

Drury, R.A.B., Wallington, E.A. and Cameron, S.R., 1967. Carleton's histological technique. Oxford University Press, London. 432p.

Hassan, A.N.U.A.R., Ambak, M.A. and Samad, A.P.A., 2011. Crossbreeding of Pangasianodon hypophthalmus (sauvage, 1878) and Pangasius nasutus (bleeker, 1863) and their larval development. Journal of Sustainability Science and Management, 6(1), pp.28-35. http://akuatrop.umt.edu.my/wp- 
content/uploads/sites/51/2014/08 /4.June11.pdf

Kamler, E., 2012. Early life history of fish: an energetics approach (Vol. 4). Springer Science \& Business Media. Van Nostrand Reinhold, London. p. 267. http://jssm.umt.edu.my/files/ 2012/01/4.June11.pdf.

Lavens, P. and Sorgeloos, P., 1996. Manual on the production and use of live food for aquaculture (No. 361). Food and Agriculture Organization (FAO). 295 p. https://www. cabdirect.org/cabdirect/abstract/19 971409717

Pham, T.L., 2001.Studies on the early development and larval rearing of Oxyeleotris marmoratus (bleeker) (Doctoral dissertation, Fakulti Sains dan Teknologi). Kolej University of Science and Technology Malaysia, Kuala Terengganu. $122 \mathrm{p}$.

Morni, M.M., 2003. Study on crossbreeding between Asian and African catfish (Clarias macrocephalus and Clarias gariepinus) and some aspects of the hybrid larvae development and rearing. Master of Science Thesis. Kolej University of Science and Technology Malaysia. 137p.

Petkam, R. and Moodie, G.E.E., 2001. Food particle size, feeding frequency, and the use of prepared food to culture larval walking catfish (Clarias macrocephalus). Aquaculture, 194(3-4), pp.349-362. https://doi.org/10.1016/S00448486(00)00524-X.

Roberts, R.J., 2012. Fish pathology. Ed 4. Blackwell Publishing Ltd, London. $581 \mathrm{p}$.

Schiemer, F., Keckeis, H. and Kamler, E., 2002. The early life history stages of riverine fish: ecophysiological and environmental bottlenecks. Comparative Biochemistry and Physiology Part A: Molecular \& Integrative Physiology, 133(3), pp.439-449.https://doi.org/10.

1016/S1095-6433(02)00246-5.
Southgate, P.C. and Lucas, J.S., 2003. Reproduction, life cycles and growth. Blackwell Publishing. Oxford.pp.111-122.

Tuan, N.A., Cacot, P. and Lazard, J., 2002. Larval rearing of the Asian Catfish, Pangasius bocourti (Siluroidei, Pangasiidae): alternative feeds and weaning time. Aquaculture, 212(1-4), pp.115-127. https://doi.org/10.1016/S00448486(01)00737-2.

Verreth, J.A., Torreele, E., Spazier, E., Van der Sluiszen, A., Rombout, J.H., Booms, R. and Segner, H., 1992. The development of a functional digestive system in the African catfish Clarias gariepinus (Burchell). Journal of the World Aquaculture Society, 23(4), pp.286298. https://onlinelibrary.wiley. com/doi/abs/10.1111/j.17497345.1992.tb00792.x.

Walford, J. and Lam, T.J., 1993. Development of digestive tract and proteolytic enzyme activity in seabass (Lates calcarifer) larvae and juveniles. Aquaculture, 109(2), pp.187-205. https://doi.org/ 10.1016/0044-8486(93)90215-K. 